\title{
Do Profitable And Non-Profitable Firms Pay Executives Differently?
}

Martin Gritsch, (Email: gritschm@wpunj.edu), William Paterson University of New Jersey Tricia Coxwell Snyder, (Email: snydert@wpunju.edu), William Paterson University of New Jersey

\begin{abstract}
In the past decade, there has been a considerable increase in the use of stock options as a form of executive compensation. While agency theorists study the relationship between performance based pay and job productivity, they have not addressed whether executive compensation is impacted by a firm's profitability. Profitable firms may pay executives more incentive-based pay, to reward their managers for a good job. In contrast, non-profitable firms may be willing to pay executives more in the way stock options to attract better managers. We find that a CEO's probability of receiving stock options increases if he/she is employed by a profitable firm. However, the amount received by such a CEO is substantially less than the amount received by the average CEO at a non-profitable company.
\end{abstract}

\section{INTRODUCTION}

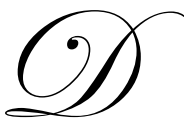

uring the 1990s, there was a considerable increase in the use of stock options as a form of executive compensation. From 1992 to 2000, executive stock options compensation more than tripled. In 1992, slightly more than 60 percent of the top five executives in the S\&P 1,500 companies received some form of stock option compensation, accounting for less than a third of their total compensation. By 2000, over 80 percent of these executives were paid in stock options, accounting for over half of their compensation (cp. Table 1).

Table 1: Summary Of The Mean And Standard Deviations Of Stock Option Values, Salary, And Stock Option Share Of Total Compensation From 1992 To 2000

\begin{tabular}{|c|c|c|c|c|c|c|}
\hline \multirow{2}{*}{ Year } & \multicolumn{2}{|c|}{ Stock Options (in \$1,000) } & \multicolumn{2}{c|}{ Salary (in \$1,000) } & \multicolumn{2}{c|}{$\begin{array}{c}\text { Stock Options as Share of Total } \\
\text { Compensation }\end{array}$} \\
\cline { 2 - 7 } & Mean & $\begin{array}{c}\text { Standard } \\
\text { Deviation }\end{array}$ & Mean & $\begin{array}{c}\text { Standard } \\
\text { Deviation }\end{array}$ & \multicolumn{2}{c|}{$\begin{array}{c}\text { Mean } \\
\text { Deviationdard }\end{array}$} \\
\hline 1992 & 435.9 & $1,242.4$ & 326.5 & 199.7 & 0.33 & 0.21 \\
\hline 1993 & 472.3 & $1,236.5$ & 327.5 & 206.9 & 0.35 & 0.21 \\
\hline 1994 & 638.1 & $1,706.0$ & 327.1 & 203.1 & 0.38 & 0.21 \\
\hline 1995 & 624.5 & $1,734.1$ & 339.7 & 219.0 & 0.36 & 0.21 \\
\hline 1996 & 852.1 & $2,177.3$ & 343.0 & 221.5 & 0.42 & 0.23 \\
\hline 1997 & $1,251.7$ & $5,394.5$ & 349.7 & 228.3 & 0.45 & 0.24 \\
\hline 1998 & $1,303.9$ & $4,147.4$ & 364.2 & 234.8 & 0.48 & 0.23 \\
\hline 1999 & $2,007.3$ & $6,918.5$ & 379.9 & 246.1 & 0.52 & 0.23 \\
\hline 2000 & $2,415.7$ & $9,015.7$ & 405.0 & 265.4 & 0.52 & 0.24 \\
\hline
\end{tabular}

Not only has the total value of stock options increased, so has the value relative to a firm's profits. Table 2 shows the ratio of executive stock option compensation to the firm's net income. While the mean ratio is less than one percent in 1992, it is more than 8 percent in 2000, i.e., by the end of the decade, the average firm issues stock options to their CEO valued at more than 8 percent of net income. We consider this to be a rather large number. 
Table 2: Mean Ratio Of Stock Options To Earnings

\begin{tabular}{|c|c|}
\hline Year & Ratio \\
\hline 1992 & 0.009 \\
\hline 1993 & 0.037 \\
\hline 1994 & 0.043 \\
\hline 1995 & 0.034 \\
\hline 1996 & 0.033 \\
\hline 1997 & 0.057 \\
\hline 1998 & 0.051 \\
\hline 1999 & 0.077 \\
\hline 2000 & 0.082 \\
\hline Total & 0.051 \\
\hline
\end{tabular}

While agency theorist suggest that incentive-based pay, such as stock options, help to better connect the principal (shareholder) and the agent (executives), Sanders (2001) suggests that stock option compensation may be used as a tool to attract better managers.

However, the 1990s increase in stock option grants is becoming increasingly controversial as disclosures emerge that CEOs of companies such as Enron Corp. and Global Crossing reaped millions of dollars by exercising their stock options as the public held onto stock that became worthless. For example, in 2000 the Enron Chairman, Kenneth Lay realized 123.4 million in exercised stock options, while his company reported a net loss. Similarly, the CEO of Global Crossing, Mr. Annunziata, received 182 million dollars worth of stock options, while the company reported a negative net income of $\$ 10,500,000$.

In this paper, we examine whether there is a difference in the use of stock option compensation between profitable and non-profitable firms.

\section{LITERATURE REVIEW}

Brookfield and Ormrod (2000), Mehran (1995), Dhillon and Ramirez (1994), Rosen (1990), and Jensen and Meckling (1976) address whether the growing number of stock options impacts firm performance. These studies analyze the impact of stock options and whether they improve employee relations, attract better workers, increase cash flows, reduce agency costs, promote shareholder wealth, and create takeover defense strategies to improve overall firm performance.

Jensen and Meckling (1986) suggests that one of the biggest principal-agent conflicts between executives and shareholders arises over the internally generated cash flow, where managers finance non-profitable investments instead of awarding shareholders dividends. Thus, an important question is whether stock and stock options reduce this cash flow issue. In a similar study, Mehran (1992) suggests that a firm's leverage ratio and the percent of the executive's total incentive plan compensation are highly related, reducing the agency theory problem. These agency theorists suggest that firms may want to pay the executives of profitable firms in "performance based" compensation, such as stock options, to better match the principal (stakeholders) with the agent (executives). While this is commonly accepted theory, other economists suggest that non-profitable firms may try to attract better executives by paying more in stock option compensation.

Sanders (2001) suggests that while one might think that these variables are positively associated with the value of stock options granted (as a "reward" for good results), the opposite might be the case due to a tendency to grant stock options in companies which perform poorly. This might happen if stock options are used in an attempt to attract executives who can help turn around the company. Similarly, some firms may prefer to pay executives stock options instead of salary due to cash constraints. According to Iyengar (2003), loss-making firms lower dividends as executive compensation increases. 
While these economists have addressed the principal agent problem, they have not examined whether stock options executive compensation is different among profitable and non-profitable firms. Thus, we want to examine if profitable and non-profitable firms pay executives differently.

\section{DATA AND EMPIRICAL TECHNIQUE}

We collect annual compensation data from Standard and Poor's ExecuComp database from 1992 to $2000 .{ }^{1}$ One advantage of the ExecuComp database is its large size. It follows a total of 2,412 companies over times, which are or were a member of the S\&P 1,500 (consisting of the S\&P 500, the S\&P MidCap 400, or the S\&P SmallCap 600). Since each company must provide information about the top five executives in each year, the overall number of records is substantial. Initially, our data set includes 93,867 individual-year observations. However, we exclude observations for executives whose reported value of stock options granted in a certain year is missing. ${ }^{2}$ Additionally, we restrict our analysis to individuals who are identified as the CEO of their respective companies. Summary statistics for the variables included in our estimations are presented in Table 3.

Table 3: Means And Standard Deviations Of Variables Used In Estimations

\begin{tabular}{|l|c|c|}
\hline \multicolumn{1}{|c|}{ Mean } & Standard Deviation \\
\hline Dependent Variables & 0.72 & 0.45 \\
\hline $\begin{array}{l}\text { Stock option indicator } \\
\text { (0 if no stock options, } \\
1 \text { if any stock options) }\end{array}$ & & \multicolumn{2}{|c|}{} \\
\hline Black-Scholes value of stock options (\$ thousand) & $2,011.72$ & 98463.64 \\
\hline Independent Variables & \multicolumn{1}{|c|}{} \\
\hline Annual NASDAQ average & $1,671.27$ & $10,031.48$ \\
\hline Firm's sales (\$ million) & $3,801.25$ & 12.66 \\
\hline Firm's return on assets & 3.73 & 792.03 \\
\hline $\begin{array}{l}\text { Firm's net income } \\
\text { (\$ million) }\end{array}$ & 219.65 & $18,541.63$ \\
\hline Firm's market value (\$ million) & $5,435.73$ & 0.22 \\
\hline Small firm & 0.05 & 0.37 \\
\hline Large firm & 0.16 & 307.41 \\
\hline CEO's salary (\$ thousand) & 565.21 & 0.35 \\
\hline Profitability indicator (0 if loss, 1 if profit) & 0.85 & \\
\hline
\end{tabular}

To examine whether a firm's profits impacts executive stock option compensation we first estimate a logit model in which we regress a binary variable, which indicates whether a CEO received stock options in a given year or not, on a number of control variables and a binary variable which indicates whether the CEO's firm was profitable in that year or not. This allows us to determine whether executives are more likely to be compensated with stock options if they are employed by a profitable firm (or possibly vice versa). More specifically, we estimate equation (1) using a logit model:

$$
\text { ANYSO }_{i}=\alpha+\beta_{\text {PROFIT }} \text { PROFIT }_{i}+\sum_{k} \beta_{k} x_{k, i}+\varepsilon_{i}
$$

where $\mathrm{ANYSO}_{i}$ is a binary variable which takes on the value one if executive $i$ was compensated with stock options at all in a given year, zero otherwise. PROFIT ${ }_{i}$ is our variable of main interest, and it takes on the value one if the CEO's

\footnotetext{
${ }^{1}$ The Security and Exchange Commission (SEC) began to require public firms in 1992 to disclose grants of stock options to their top five executives as well as their option exercise activity in their proxy statements.

${ }^{2}$ According to private communication with Standard \& Poor's, the value of stock options is missing when an executive did receive stock options in a year, but the company did not disclose sufficient information to allow for the calculation of their Black-Scholes value.
} 
firm was profitable that year, zero otherwise. The $x_{k, i}$ is a vector of control variables (as presented in Table 3), $\alpha$ and the $\beta$ 's are parameters to be estimated, and $\varepsilon_{i}$ is an error term.

The average NASDAQ value is included to control for the overall increase in the stock market. Following Mehran (1995), we also include firm level data to control for firm performance by incorporating the firm's annual sales, return on assets, net income (after extraordinary items and discontinued operations), and market value. As additional controls at the firm level, we include one dummy variable each for small companies (smallest 10 percent in terms of number of employees) and large companies (largest 10 percent). The rationale for these two dummies is that small firms may be facing cash flow problems, creating the incentive to compensate CEOs with stock options instead of salary to help maintain a higher cash flow position. On the other hand, larger firms may have a more established history of offering stock options and economies of scale or scope when issuing stock options. At the individual level, we include the value of a CEO's salary since there is some evidence that CEOs with high salaries are also the ones who receive large amounts of stock options.

In a second estimation, we examine the quantitative effect of a firm's profitability on the amount of stock option compensation a CEO receives. Specifically, we estimate:

$$
S O_{i}=\gamma+\delta_{\text {PROFIT }}(\text { PROFIT })+\sum_{k} \delta_{k} x_{k, i}+\eta_{i}
$$

where $S O_{i}$ is the (Black-Scholes pricing model) value of stock options granted to executive $i$ in a given year. The other variables and parameters are analogous to equation (1).

\section{EMPIRICAL RESULTS}

Table 4 shows the results of the estimation of the logit model.

Table 4: Logit Estimation Results For Stock Option Indicator (Reported Estimates Are Odds Ratios, Standard Errors In Parentheses)

\begin{tabular}{|c|c|}
\hline & $\begin{array}{c}\text { Stock Option Indicator } \\
\text { (0 if no stock options, } 1 \text { if any stock options) }\end{array}$ \\
\hline \multirow[t]{2}{*}{ Annual NASDAQ average } & 1.00018 \\
\hline & $(0.00002) * *$ \\
\hline \multirow[t]{2}{*}{ Firm's sales (\$ million) } & 1.00002 \\
\hline & $(0.00001)^{* *}$ \\
\hline \multirow[t]{2}{*}{ Firm's return on assets } & 0.99631 \\
\hline & $(0.00205)$ \\
\hline \multirow[t]{2}{*}{ Firm's net income (\$ million) } & 1.00013 \\
\hline & $(0.00006)^{*}$ \\
\hline \multirow[t]{2}{*}{ Firm's market value (\$ million) } & 0.99999 \\
\hline & $(0.00001)$ \\
\hline \multirow[t]{2}{*}{ Small firm } & 1.41932 \\
\hline & $(0.13497)^{* *}$ \\
\hline \multirow[t]{2}{*}{ Large firm } & 1.00553 \\
\hline & $(0.06794)$ \\
\hline \multirow[t]{2}{*}{ CEO’s salary ( $\$$ thousand) } & 1.00062 \\
\hline & $(0.00009) * *$ \\
\hline \multirow[t]{2}{*}{ Profitability indicator ( 0 if loss, 1 if profit) } & 1.05466 \\
\hline & $(0.0725)$ \\
\hline Observations & 12,841 \\
\hline "R-Squared" & 0.02 \\
\hline
\end{tabular}


As can be seen from the table, more than half of the estimates are highly statistically significant. The control variables typically show the expected sign and magnitude. Interestingly, being employed by a small firm increases a CEO's probability of receiving stock options substantially. An inspection of the estimate for our variable of main interest shows that a CEO who is employed by a profitable firm has an approximately 5 percent higher probability of receiving stock option compensation than a CEO of a company that showed a loss that year. Note, however, that the standard error is quite large, and this estimate is not statistically significant at any standard level.

The estimation of equation (2) led to the following results:

Table 5: Ordinary Least Squares Regression Results For Stock Option Value (Standard Errors In Parentheses)

\begin{tabular}{|l|c|}
\hline & $\begin{array}{c}\text { Value of stock options (Black-Scholes method) } \\
\text { (\$ thousand) }\end{array}$ \\
\hline Annual NASDAQ average & 1.02 \\
\hline & $(0.08)^{* *}$ \\
\hline Firm's sales (\$ million) & -0.02 \\
\hline & $0.01)$ \\
\hline Firm's return on assets & 14.61 \\
\hline & $(7.71)$ \\
\hline Firm's net income (\$ million) & -0.50 \\
\hline & $(0.17)^{* *}$ \\
\hline Firm's market value (\$ million) & 0.13 \\
\hline & $(0.01)^{* *}$ \\
\hline Small firm & -294.83 \\
\hline & $(380.39)$ \\
\hline Large firm & 64.51 \\
\hline & $(250.53)$ \\
\hline CEO's salary (\$ thousand) & 1.55 \\
\hline & $(0.31)^{* *}$ \\
\hline Profitability indicator (0 if loss, 1 if profit) & -809.30 \\
\hline & $(275.45)^{* *}$ \\
\hline Observations & 12,841 \\
\hline R-Squared & 0.07 \\
\hline & $* * *$ statistically significant at 1\% \\
\hline
\end{tabular}

Just like in the first estimation, five of the nine estimates exhibit high estimation precision with p-values of 0.003 or smaller. Interestingly, an increase in a firm's net income is associated with a smaller amount of stock option compensation for the CEO. Conversely, lower-income firms pay more in stock options to their CEO. This is quite plausible and consistent with previous results in the literature since stock options can be given as potentially lucrative form of compensation by firms with difficulties to CEOs who can "turn the company around." Also note that being the CEO of a small firm, on average, reduces stock option compensation by a magnitude of almost $\$ 300,000$ annually. This is an interesting result given that the probability of receiving stock options is actually greater in a small firm (see Table 4). It shows the importance of examining this issue both in terms of the likelihood that a firm issues stock options to its CEO as well as the quantitative effect (as a dollar figure). Finally, the estimate that is the main focus of this paper shows a substantial result: Profitable firms, on average, compensate their CEO substantially less in stock options than firms that show a loss. The estimate is quite large (in excess of $\$ 800,000$ annually, and it is highly statistically significant.

\section{CONCLUSIONS}

This paper contributes to the growing body of literature dealing with the relatively new issue of stock option and salary compensation for executives and how a firm's profitability impact this mix. In light of the current Enron 
scandal and the executives' abuse of stock option compensation, this literature is very important for tax and accounting policy makers.

Estimation of two different, yet related specifications yielded the following result: While a CEO's probability of receiving stock options as part of his or her compensation package increases (by approximately 5 percent) if he or she is employed by a profitable firm, the amount received by such a CEO is substantially less (approximately $\$ 800,000$ less per annum) than the amount received by the average CEO at a company that shows a loss.

\section{REFERENCES}

1. Brookfield, David and Ormrod Phillip (2000) Executive Stock Options: Volatility, Managerial Decisions and Agency Costs, Journal of Multinational Financial Management, v10, n3-4, Sept.-Dec., pp. 275-95.

2. Jensen, M. C. and W. Meckling (1976) Theory of the Firm: Managerial Behavior, Agency Costs and Ownership Structure, Journal of Financial Economics, v3, n4 October, pp.305-60.

3. Mehran, H. (1995) Executive Compensation Structure, Ownership, and Firm Performance, Journal of Financial Economics, v38, pp. 163-184.

4. Mehran, H. and J. Tracy (2001) The Effect of Employee Stock Options on the Evolution of Compensation in the 1990sof Employee Stock Options on the Evolution of Compensation in The Effect of Employee Stock Options on the Evolution of Compensation in the 1990s, Federal Reserve Bank of New York Economic Policy Review, v7, n3, December, pp.17-34.

5. $\quad$ Rosen, Corey (1990) The Record of Employee Ownership, Financial Management, 19, 1, spring, pp. 3947.

6. Sanders, G. (2001) Behavioral Responses of CEOs to Stock Ownership and Stock Options, Academy of Management Journal, v44, n3, pp. 473-492.

7. Yermack, D. (1995) Do Corporations Award CEO Stock Options Effectively? Journal of Financial Economics, v39, pp. 237-269. 